DOI: $10.15642 /$ JIIS.2016.10.1.113-138

\title{
THE PLURALISM OF ISLAMIC ECONOMIC LAW Dialectic of Moslem and non-Moslem in the Development of Sharia Banking in Indonesia
}

\author{
Mohamad Nur Yasin \\ UIN Maulana Malik Ibrahim, Malang - Indonesia | yasinm.nuryasin@yahoo.co.id
}

\begin{abstract}
The Fact that Moslems live in various places with diversity in terms of sociological, geographical and cultural aspect leads to law pluralism. Both western law and Islamic law acknowledge the concept of diversity of law (law pluralism). In this regard, this essay tried to show that the development of Islamic economic law including the sharia banking in Indonesia has unique characteristic since its development has the involvement of Moslems and NonMoslems. The essay shows that the involvement of both Moslems and non-Moslems in the formulation process of Sharia Banking Act and its implementation is affected by ideological and political argumentation, juridical and economic argumentation, and social cultural perspective. The process involving Moslem and non-Moslem in the formulation process and implementation of Sharia Banking Act can be considered relational dialectic that consist of thesis, antithesis, and synthesis.
\end{abstract}

Keywords: Moslem, non-Moslem, Islamic economic law, Sharia banking, Islamic banking.

\section{Introduction}

The creation of mankind into males and females, tribes, and groups, ${ }^{1}$ have some consequences on scattering society in various places and raises varied and many choices of law, ${ }^{2}$ among people, so it forms law pluralism. There are at least three stages of the development of law pluralism concept. First concept is law pluralism as a situation in

\footnotetext{
1 Al Qur'an, al-Hujurat: 13.

2 Al Qur'an, al-Maidah: 48.
} 
which two or more law systems co-exist in one society. ${ }^{3}$ Here, it also means the presence of more than one law in the community. ${ }^{4}$ Second concept is law pluralism as interaction across various legal system existing within a society. ${ }^{5}$ Third concept is law pluralism in the sense of constellation between various characters of legal systems. ${ }^{6}$ To sum up, the concept of law pluralism has developed from dicotomic stage to integration and then finalises at interdependence. This is even particularly true when we speak about the connection at international, national, and local law.

In the context of Islamic law, the qawl qadim and qawl jadid formulation developed by Imam Syafi'i show that different place and time really contributes to the choices of law. ${ }^{7}$ According to Marcus Tullius Cicero, where there are people, there will also be law (ubi societas ibi ius). In other words, law pluralism tends to develop where community lives with all diverse sociological and philosophical characters. ${ }^{8}$ Thus, the character of law is affected by the configuration of social and philosophical values which round the reality of society.

The historical and contemporary Indonesia shows that the living law is law imbued by social and philosophical values that grows in society. Among living law is law governing person as legal subject (naturalijke person) and inter law subject of institution (rechtperson) which includes economic law.

Ideally, the unavoidable interaction between law and economic does not erase the essence and the existence of law as dimension that must be independent and autonomous. Max Weber stressed that law is relatively autonomous, in spite of being affected by the economic system. In fact, the law also affects the dynamics of economic, mechanism, and social aspect within the community. That being said, the economic situation does not necessarily form a new law system.

\footnotetext{
${ }^{3}$ Sally Engle Merry, "Legal Pluralism," in Law and Society Review, 22 (1988), p. 870.

${ }^{4}$ John Griffiths, "What is Legal Pluralism," in Journal of Legal Pluralism and Unofficial Law, 24 (1986), p. 1.

${ }^{5}$ Keebet von Benda-Beckmann, "The Context of Law," 8th International Congress of the Commission on Folk Law and Legal Pluralism: Legal Pluralism and Unofficial Law in School, Economic, and Political Development, Chiang Mai (April 2002), p. 1.

${ }^{6}$ Ibid.

${ }^{7}$ Muhammad Ali as-Sayis, Tarikh al-Fiqh al-Islamy (Egypt: n.p., 1957), p. 104.

8 Soerjono Soekanto, Mengenal Sosiologi Hukum (Bandung: Alumni, 1986), p. 9.
} 
Although it is not determined by economic power, law is a crucial and reasonable 9 element in society. Max Weber said that law is a major factor in economic development. ${ }^{10}$ In this context, Adam Smith emphasized that the purpose of justice is protecting every one from the loss. ${ }^{11}$

To promote economic justice, what needed is a strong national law. The establishment of strong and effective national law in the field of economic requires diverse law materials (pluralism of law material). In Indonesia, material of law is also called the law of materiil and is named in accordance to the source of law be it Islamic, western, and customary law. ${ }^{12}$ As for the national law material, there are some aspects of Islamic law and one aspect of them, that is very contributive to national development, is Islamic economic law. According to Muhammad Nejatullah Shiddiqi, there are three important elements of Islamic economic; money, investment, and banking. ${ }^{13} \mathrm{Up}$ to April 2015, data shows that there are 12 units of Sharia General Bank in Indoesia and the network of offices of Sharia General Bank in Indonesia reaches 2135 units. In addition, the numbers of Sharia Business Unit is 22 units and networks of UUS office reach 325 units. Similarly developing fast, Sharia Micro Finance Bank now already are 162 units and the networks of BPRS offices in Indonesia are 471 units. ${ }^{14}$

Unlike islamic family law (al-ahwal al-shakbshiyyah) that is specifically limited for Moslems, islamic law in the field of sharia banking has the flexibility to be implemented not only by muslems, but also by nonMoslems. As a matter of fact, the customers of Sharia banking who are non-moslems is quite high in number. The phenomenon in Kupang,

9 M.D.A. Freeman, Lloyd's Introduction to Jurisprudence (London: Sweet \& Maxwell Ltd, 2001), p. 663

10 David Trubek, "Max Weber On Law and The Rise of Capitalism", Wisconsin Law Review, 3 (1972), p. 720.

11 R.L. Meek, D.D. Raphael and P.G. Stein, Lectures on Jurisprudence (Indianapolis: Liberty Fund, 1982), p. 9.

12 Qadri Azizy, Hukum Nasional, Eklektisisme Hukum Islam dan Hukum Umum (Jakarta: Teraju, 2004), p. 3.

${ }_{13}$ M. Nejatullah Siddiqi, Issues in Islamic Banking (London: Islamic Foundation, 1983), p. 1.

14 "Jaringan Kantor Perbankan Syariah", http://www.bi.go.id. Accessed on June 22, 2015. 
East Nusa Tenggara (NTT) and in Manado, North Sulawesi can be examples. According to data of Bank Muamalat Indonesia (BMI) Kupang, NTT, the number of BMI customers is 8.200 persons with 3226 customers of them are non-Moslem. ${ }^{15}$ Similarly, data of Bank Sharia Mandiri (BSM) in Manado in 2013 shows that there are 1200 non-Moslem customers who use muräbahah financing scheme. ${ }^{16}$

As a matter of fact, Kupang and Manado where the majority of its population is non-Moslems turn out to be having quite significant numbers of customers. This phenomenon is very unique and interesting and this is also why I do research on this. In my opinion, it is quite urgent to know the argumentations behind involvement of both Moslems and non-Moslems in the development of sharia banking in Indonesia. Moreover, research on this is very rare. This research is aimed at filling the gap in the researches on the dialectic of Moslem and non-Moslem in the development of sharia banking in Indonesia.

According to Lawrence $M$ Friedman, the power of law is determined by three elements. First, the validity of law material and contents (legal substance). Second, the supporting and up dated facilities and infrastructures which also includes authoritative law enforcement (legal structure). Third, the culture of pro-law society (legal culture). ${ }^{17}$ This essay will only focuces on legal culture aspect, the legal awareness, as it is the main aspect especially in relation to community involvement. The dynamics of sharia banking in Indonesia involving Moslem and non-Moslem includes three levels. First, level of formulation process of Act No 21 of 2008 on Sharia Banking. Second, level of substance in the Act of Sharia Banking. Third, level of implementation in sharia banking pinciples. The overall levels were held in critical and simultaneous dialectic interplay between Moslem and non-Moslem.

This study intends to answer two important questions; First is why Moslem and non-Moslem are involved in the development of sharia

15 Rizan Annaafi M, "Pendapatan dan Pemanfaatan Dana Nasabah non-Moslem oleh Bank Muamalah Indonesia Cabang Kupang NTT", Bachelor thesis, Sharia Faculty of UIN Sunan Kalijaga Yogyakarta, 2009, p. 44, http://digilib.uin-suka.ac.id. accessed on June 23, 2015

${ }^{16}$ Fanny Yunita Sri Rejeki, "Akad Pembiayaan Murabahah Dan Praktiknya Pada PT Bank Syariah Mandiri Cabang Manado”, Lex Privatum, 1, 2 (Apr-Jun/2013), p. 26, ejournal.unsrat.ac.id. accessed on June 21, 2015.

${ }^{17}$ Lawrence M. Friedman, The Legal System, a Social Sentence Perspective (New York: Rusell Sage Foundation, 1975), pp. 16-17. 
banking in Indonesia and Second is how actually is the dialectic model of Moslem and non-Moslem in the development of sharia banking.

\section{The Stimulating Argumentation between Moslem and non- Moslem in the Development of Sharia Banking in Indonesia}

There are at least three significant arguments can explain the involvement of Moslem and non-Moslem in the development of sharia banking in Indonesia; ideological and political argument, juridical and economic argument, also, social and cultural argument. At the same time, those three can also be reasons behind reluctance towards the sharia banking.

\section{The Ideological and Political Argument}

Ideological and political argument are characterized by religious arguments combined with political sentiment when it come for supporting or rejecting sharia banking. This can be seen from the rejection of a number of Bali residents to sharia banking. According to I Gusti Ngurah Arya Wedakarna Mahendradatta Wedasteraputra Suyasa, Rector of Mahendradatta University of Bali, Bali's people have implemented Pancasila economy and customs. He argued that Sharia economy will become problematic when there is a hidden agenda to ruin Balineses' economy. Furtheromore, he also asserts that Bali's people followed economy of Pancasila not economy of only one religion. He also sugeests that Bali has its own way and say that "We have had our economic system and we do not need to adopt it from outside. The sharia economic movement could be implemented in Malaysia, Middle East, and several other Islamic countries, but it cannot be implemented in Bali." Interestingly, he also argues that 'sharia economy only strengthens and gives advantages for one religious group. The shariah economy was good for them, but it was not good for us. We deeply regret the fact that the sharia economy as it seems more popular than Pancasila economy. ${ }^{18}$

Here, I see that the ideological and political dimensions of rejection among several Bali's people towards sharia banking are very clear. They actually want to say that sharia banking was not in accordance with the teachings of Hinduism. However, they prefer to argue that sharia banking was not in accordance with the economic of

18 "Menjawab Resah di Pulau Dewata”, http://stabilitas.co.id/2014, accessed on June 12, 2015. 
Pancasila. This is a common trend as people in Bali seem to avoid to use religion as reason behind their opposition to something. Instead, they will argue that those rejectedthings, including Sharia economy, is not in accordance with their culture or even with Pancasila. Here, islamic or sharia economic is considered as part of islamization at Bali.

\section{The Juridical and Economic Argument}

Juridical and economic argument is characterized by the existence of legal dimension in pair with economic dimension, such as the usage of "profit sharing" and "economic justice" concept to give support or rejection to sharia banking. Juridical and economic argument can be seen in various statement.

According to Rifatul Mahmudah, the reason why 95.4\% passion of non-Moslem become clients of Bank of CIMB Niaga Sharia of Semarang, range fromthe location factor, service, religious stimuly, reputation, promotion, and profit sharing. From those various factors, profit-sharing was the most dominant factor. ${ }^{19}$ Meanwhile, Nusyirwan Ismail, head of BNI Syariah Branch of Medan argues that many nonMoslems choose the Islamic banking services as it is seen to be more just. ${ }^{20}$

In the perspective of Santo Thomas Aquinas, there are two kinds of justice; general justice (justisia generalis) and special justice (justisia specialis). Special justice includes two points. First, distributive justice which means equity to every man according to his own merits and second is the commutative justice which is entitled to everyone regardless any merit or deed. ${ }^{21}$ In the context of sharia banking, it is very clear that distributive justice is more dominant than commutative justice showcased by the principle of profit and loss sharing between the owner of capital (shähibu al-māal) and fund management (mužărib) which is based on the level of the contribution of each party both in terms of funds and services. For non-Moslem, distributive justice

19 Rifa'atul Machmudah, Faktor-Faktor Yang Mempengarubi Minat Nasabab Non Moslem Menjadi Nasabah Di Bank Syariah (Studi Pada Bank. Cimb Niaga Syariab Cabang Semarang), Fakultas Syariah IAIN Walisongo, 2009, p. 60. http://library.walisongo.ac.id, accessed on July 6, 2015

${ }^{20}$ Ruslan Burhani, Nasabah Non Moslem Minati Perbankan Syariah, Thursday, December 28, 2006, http://www.antaranews.com / berita/, accessed on June 12, 2015.

21 Muhammad Erwin, Filsafat Hukum, Refleksi Kritis terhadap Hukum (Jakarta: Raja Grafindo Persada, 2012), p. 226. 
could become a guarantee of legal certainty. Although they are nonMoslem, customers will still receive equal legal treatment (equality before the law) and will no be discrimated against.

Interestingly ironic, the rise of number of non-Moslems as customers of necessarily means that the Moslems will support it even more. There are still several critics. Among them is the Central Executive Board of Nahdlatul Ulama (PBNU) that has run the review against the concepts and practices of banking operated by sharia banking and sharia financial institution in Indonesia. Abdul Jalil, a member of Fatwa Commission (Bahth al-Masáil) of NU in 2015, critisizes that at the substance level, sharia banking and conventional banking is not much different. He objects some who argue the difference between legality (shari) and "non-legality (non-shari) is measured from contract ('aqd). He criticized it as a simplification. He then ellaborated as follows:

"On sharia banking, it is found a contract of al-ijarah almuntahiyah bit tamlik (IMBT). What are differences between IMBT and leasing in conventional banking, cooperative, and sharia rural bank (Baitul mal wa Tamwil/BMT). Travel service companies among NU entrepreneurs get stuck on this sharia product. If initial "sharia banking" as a name, it is okay. But if shariah banking called legal (shari) just based on contract (('aqd), service, and her maid are wearing Islamic attributes, of course the answer is "no". NU must say that sharia banking is equal to conventional banking or conventional banking also legal (shari)". ${ }^{22}$

I argue that Abdul Jalil's critic is not all relevant because of two reasons. First, shariah banking is not a regulator (shari'a provision maker), but a practicioner in the field that its operation must refer to the sharia principle. Based on article 1 of Act No 21 of 2008 on Sharia Banking, sharia principle is islamic law principle to refer to in performing banking activities. Sharia principles here are based on fatwa issued by authoritative institution here is the Indonesia Ulama Board (MUI) as stated in paragraph 2 of article 26 of Act No 21 of 2008 on Sharia Banking. Thus, Abdul Jalil's critic above should be directed to MUI particularly the National Sharia Council (DSN) as they are the ones

22 Alhafiz K, Jelang Muktamar Ke-33 NU, PBNU: Bank Berlabel "Syariab" di Indonesia Belum Syar'i, Ahad, 26/04/2015, http:/ /www.nu.or.id._ Accessed on June 12, 2015. 
issuing standards and principles of Sharia economics to be applied by the sharia bankings or other units.

In addition to that, jalil's reluctance to acknowledge the particularity of sharia banking and equate it with conventional banking is deficient. Equating sharia banking with conventional banking is impossible since there differences between them despite several similarities.

\section{The Social and Cultural Argument}

Social and cultural argument is marked by the existence of principle or behavior that is based on tradition or social reality as the basis or reason of rejection or support towards sharia banking. Social and cultural arguments are reflected in the statements of two nonMoslem figures, Thoby Mutis and Hermawan Kertajaya.

According to Thoby Mutis, Rector of Trisakti University of Jakarta, sharia banking is very good because there is openness and honesty in Islamic economy. Furthermore, he explains as follows; "The concept of profit sharing has already been used since the past and are now continuing it. This concept required honesty and openness in the cooperation and it is very good if it is applied in the real sector. ${ }^{23}$

Meanwhile, according to Hermawan Kartajaya, Islamic values are universal and applicable for all mankind. He further argues that the Prophet Muhammad spreads the teachings of Islam not only for Moslems. The also argues that he value of sharia marketing, which is initiated by Moslems, can inspire others. He even suggested that the more non-Moslems applying it the better. He also actively endorse sharia marketing and believe that honesty is universal. In his opinion, Sharia marketing should be known by all mankind in order to realize rahmatan li al-'alamin". ${ }^{24}$

Here, I see that the alignment or paralellity between sharia banking principles and social values of cooperation, togetherness, openness, and honesty brought Thobi Mutis to support the development of sharia banking. Analyzed from the concept of relationship between religion and custom, Thobi Mutis' commitment to sharia banking is

23 "Prof Thoby Mutis: Bank Syariah Lebih Banyak Kembangkan Musyarakah Fund", http://jaketbirukampus.blogdetik.com/2010, accessed on June 13, 2015.

24 "Asuransi Syariah, Kaya Manfaat untuk. Semua Umat", http://ekonomi. kompasiana. com/2014, accessed on June 13, 2015. 
more a receptie theory than a theory of receptio a contrario. Christian Snouck Hurgronje, the theorist of receptie, ${ }^{25}$ said that Islamic law could be applied in Indonesia if it is does not contradict the customary law. Conversely, based on Ichtiyanto's opinion, the theorist of receptio a contrario, ${ }^{26}$ customary law could applied in Indonesia it does not contradict islamic law. Thus, Thobi Mutis' support to sharia banking is also due to the fact that the sharia here does not contradict customary law. Slightly different from that, Hermawan Kertajaya's support to Islamic economic is more to his believ in the universal values brough by the prophet and hence should be applicable to all mankind.

\section{The Dialectic of Moslem and non-Moslem in the Development of Sharia Banking in Indonesia}

If we trace back the history, the dialectic of Moslem and nonMoslem in context of forming financial business institution has been there since the early era to the period of establishment of Islamic Trade Assosiation (SDI). Afterwards, there is a vacuum period, which is around 100 years, until the establishement of Bank Muamalah Indonesia (BMI) as the first Sharia General Banks in Indonesia. The success of BMI is the success of the raise of Islamic economic and if there is failure, then we can assume that it will take 50 to 100 more years to be able to grow the new institution. ${ }^{27}$

Historically, the launch of BMI by President Suharto in 1992 is the mark for the the beginning of the Sharia banking. As a starting point, this moment is actually the culmination of a long and complex process and has been through fierce debates among sharia banking academics and practitioners. At least, there are five basic assumptions that support the argumentation to establish BMI as the first sharia general bank in Indonesia. First, the mainstream of posmodernism thought. Second, the long struggle of Indonesian Moslem. Third, the continuity of islamic bank history. Fourth, Soeharto's political accommodation

25 Ichtiyanto, "Pengembangan Teori Berlakunya Hukum Islam di Indonesia", Eddi Rudiana Arief, Hukum Islam di Indonesia, Perkembangan dan Pembentukan (Bandung: Remaja Rosdakarya, 1994), p. 54.

26 Ibid., p. 55.

27 Zainul Bahar Noor, "Sebuah Mimpi, Harapan, dan Kenyataan di Hadapan”, paper on One Day Seminar of How to Business in Islamic Perspective, in Garden Palace Hotel Surabaya, September 12, 1992, p. 1 
towards Moslems. Fifth, reflection of the self-attitude, institution, and situation. $^{28}$

The phenomenon accompanying the establishment of BMI can be declared as the first effort to openly expose idea. When it resulted in some impacts then there were diverse opinions towards it either rejection or support. This is all happening in a continuing dialectical relationship. According to Baxter, in order to succeed and being accepted, the existence of dinamized relation which always evolves requires requires continuous attention. ${ }^{29}$

Hegel calls this model of dialectic with the concept of "abstractnegative-concrete" at one time and with the concept of "immediatemediated-concrete" at another time. Thinkers after Hegel put Hegel's dialectic model as "thesis, antithesis, and synthetic". To sum, the stage is as follows; it begun with statement building in a thesis and then followed by reasonings opposing the thesis. At last, there are compromises and combinations among contradictions in thesis and antithesis at the final stage that is the synthetic. ${ }^{30}$ This kind of Hegel's model of dialectic occurs in the economic life in Indonesia, especially in the Sharia banking sector with all the dyamnics.

The dynamic is not only found in in the institution level showcased by the opening of various sharia banking offices, but also in the legislation level, namely the enactment of the government regulation regarding sharia banking The emergence of sharia banking law is not separated from the politics of law in Indonesia. Similar to other fields, without political power, there is no stable economic system. For example, capitalist economic in the US is strong because of the support from American politics while socialism economic was once popular because of support from Soviet Union. Similarly, etatism economic was strong due to the support from the Old order. ${ }^{31}$

28 M. Nur Yasin. Argumen-argumen Kemunculan Awal Perbankan Syariah di Indonesia, De Jure, Journal of Sharia Faculty UIN Maulana Malik Ibrahim Malang, 2011, p. 110.

${ }^{29}$ L. A. Baxter, "A Tale of Two Voices: Relational Dialectics Theory", The Journal of Family Communication, 4/3, 4 (2004), pp. 182-192.

30 A.V. Miller, Hegel's preface to the Phenomenology of Spirit (Oxford: Clarendon Press, 1977), pp. 29-30.

31 M. Nur Yasin, Hukum Ekonomi Islam (Malang: UIN Malang Press, 2009), p. 2. 
In this context, the politic of law always has three aspects. First, the politics of law formulation. Second, the politics of law substance. Third, the politic of law enactment. ${ }^{32}$ Hence, the analysis of the dialectics between Moslems and non-Moslems is mapped accordingly, they are dialectic in the process of formulation of banking law, dialectic in the substance of sharia banking law, and dialectic in the implementation of the sharia banking principles.

\section{The Dialectic of Moslem and non-Moslem in the Formulation of Act No 1 of 2008 on Sharia Banking}

The politic of law formulation always focuses on the formulation process and the dialectic between the drafters of the law and others. Here, the most important juridical element related to sharia banking is the publication of Act No 21 of 2008 on Sharia Banking. The formulation process of Act No 21 of 2008 on Sharia Banking cannot be separated from dialectics between Moslems and non-Moslems within their identity and entity.

The dialectic in the formulation process on Sharia Banking Bill originally started from idea proposed by the commission XI of Indonesian Parliament (DPR RI). According to the Commission XI of DPR RI, Sharia banking act is necessery in order to provide a strong legal basis for all parties work in sharia banking. Based on the consideration above, DPR RI proposed the initiative of Commission XI DPR RI that is the Bill on Sharia Banking. The initiative to propose bill is incoordance with DPR RI constitutional and normative right stipulated in Article 20 paragraph 1 of Indonesian Constitution (UUD) 1945 and Article 12 letter D of DPR RI rule. ${ }^{33}$

The idea offered by Commission XI of DPR RI received strong rejection from one faction in the parliament. When the initiative of sharia banking Bill was being discussed, there was one faction in the 1999-2004 DPR RI that openly declared itself as the basis for Christians that is the Faction of Peace and Welfare Party (FPDS). FPDS is the only faction in the parliament who firmly rejects the bill on sharia banking in any form. According to FPDS, the law that is nationally binding must strengthen the concept of NKRI (United

\footnotetext{
32 Moh. Mahfud MD, Politik. Hukum di Indonesia (Jakarta: LP3ES, 2001), p. 20.

${ }_{33}$ M. Nur Yasin, "Rekonstruksi Norma Eksekusi Putusan Badan Arbitrase Syariah Nasional dalam Sengketa Ekonomi Syariah di Indonesia", Unplished dissertation, Program of Law, Law Faculty, University of Brawijaya, 2012, p. 173.
} 
Country of Republik Indonesia) which is based on Pancasila principles. They also argue further that the ideology of national integration does accommodate the values of multiculturalism and pluralism. A spokesman of FPDS, Retna Rosmanita Situmorang said that all things concerning sharia banking have been regulated in Law No 10 of 1998 on Banking. So, there is no need to have special law governing the activities of sharia banking. ${ }^{34}$

The opposite of FPDS is Faction of Star Reformation Party (FPBR). Here, FPBR firmly welcomed and supported the proposal of DPR RI. In their argument, FPBR stated that the needs of Indonesian Moslems to sharia banking are real and are manifestation from their needs to sharia-based business. Therefore, there is a real need for the specific law ggoverning it.. ${ }^{35}$ In addition, Faction of Partai Bintang Pelopor Demokrasi (FPBD) argued that this sharia banking bill must be enacted for the sharia banking able to operating. They further argue that the existing regulations is not sufficient. And, according to them, as long as sharia banking practices are still under the conventional banking shadow, expanding operational network is difficult. ${ }^{36}$

It is interesting to also see other faction's position towards the proposed initiatives. Faction of Democratic Indonesia Struggle Party (FPDIP) for exampe chosen to support it and argue that there is a need for a strong legal basis for practices of sharia banking. They also believe that such specific act or law will not be problematic since it will also be limited by the principle of prudence and compliance to the existing Act and regulation. In their logic, the specialty of sharia banking in this Bill should not make Law on Banking and other financial services collide. The purpose of completing the Bill is merely to enhance sharia banking role in the people's economic empowerment. ${ }^{37}$

Similarly, Faction of Democratic Party (FPD) also see that the provision on shariah banking is aimed at improving people's welfare. Sharia banking bill should include general policy, business entities

34 "Opinion of FPDS DPR RI to Bill of Sharia Banking", Memory Risalab (Minute of Meeting), 6 June 2007.

35 Yasin, "Rekonstruksi Norma, p. 173.

36 "Opinion of FBPD DPR RI to Bill of Sharia Banking", Memory Risalah (Minute of Meeting), 6 June 2007.

37 "Opinion of FPDIP DPR RI to Bill of Sharia Banking", Memory Risalab (Minute of Meeting), 6 June 2007. 
policy, institutional, facilities and initiative of sharia banking activities, taxation, employment, and protection. All aspects must be completely accommodated in order to meet people's needs and to create efficient and competitive banking system. Also, it refers to the prudence of banking, compliance on syariah principle, and the obligation of risk management. So, it supports real sector through activities of profit sharing financing for solving people's problems. ${ }^{38}$ The government expects the initiative of DPR's Bill on Sahria banking can be perfected in order not to cause disharmony among existing regulation. ${ }^{39}$

When the second discussion on sharia banking was held by DPR RI period of 2004-2009, Faction Demokrasi Kasih Bangsa (FDKB), a small Christian party rejected the Bill on sharia banking. Interestingly, at the plenary session of DPR RI in 2008, PDIP also rejected the bill. However, the bill is approved to be the act trough the voting that resulted in more supporters than those who reject. So that, the Bill was approved to be the Act No 21 of 2008 on Sharia Banking.

Finally, the dialectic has resulted in a compromise. This fact is shown by the change of FPDKB attitude. After in-depth study on sharia banking, FPDKB made the note that the banker who is proven guilty of abusing his or her authority must be given a deterrent effect. Sharia banking should be strengthened by strong and committed human resources. In addition, Moslem customers must be provided with a banking service which comply their religion. ${ }^{40}$

Referring to hegel's model of dialectic, it can be said that the dialectic betwee Moslems and non-Moslems in the formulation process on shariah banking goes through a process as follows: initiative of DPR RI Comission XI as the thesis ${ }^{41}$. And then it goes trough resistance from FPDKB which can be seen as antithesis that finally

\footnotetext{
38 "Opinion of FD DPR RI to Bill of Sharia Banking, Memory Risalah (Minute of Meeting), 6 June 2007.

39 "Opinion of FPBR DPR RI to Bill of Sharia Banking", Memory Risalab (Minute of Meeting), 6 June 2007.

40 "Opinion of FPDKB DPR RI to Bill of Sharia Banking, Memory Risalah (Minute of Meeting), 6 June 2007.

41 The thesis that offered by Commission XI was the culmination of long process of dialogues and aspirations that appear earlier, both from the Bank of Indonesia, Ministry of Finance, the Association of Sharia Scholars and Scientists in Indonesia (HISSI), internal Moslems, the Indonesian Ulama Council (MUI), and the Ministry of Religion Affairs
} 
resulted in the synthesis in the approval of the Bill to be the Act No 21 of 2008 on Sharia Banking with some notes. So, the synthesis have also arisen as a compromise between thesis and antithesis.

\section{The Dialectic of Moslem and non-Moslem in the Substance of Sharia Banking Act}

This study focuses on two basic themes of Moslems and nonMoslems dialectic related to the Act substance of Sharia Banking. First, universal principle (rahmatan li al-'́ălamin) of sharia banking. Second, principle of self-submission in the dispute resolution of sharia banking.

\section{The Principle of Universality in Sharia Banking}

As the legal basis for sharia banking in Indonesia, Act No 21 of 2008 on Sharia Banking is very crucial. There are some fundamental key words associated with sharia banking: sharia principle, economic democracy, and the principle of prudence. ${ }^{42}$ The sharia principle is based on values of justice, benefit, balance, and universality (rahmatan li al-'älamin $){ }^{43}$

The concept of rabmatan li al-'alamin that becomes the basis of sharia banking practices faces serious response from Peter Mahmud Marzuki, a non-Moslem scholar and a Professor at the Law Faculty of Airlangga University, Surabaya. According to Marzuki, sharia banking is not universal as it is originated from a legal system that is not universal, that is Islamic law. ${ }^{44}$ Clearly, Marzuki puts aspect of religion as insignificant and separate matter from the context of development of banking. If it is carefully perceived, Marzuki view has similarity with Max Weber thought. According to Weber, rational law is a legal system that is guided by fundamental principles of the law itself and it must not be a charismatic legal system such as the prophet law (law of religion). Rather it has to be a legal system that is built in and developed through justice system and drawn up by professional individuals who have already received legal education in a formal manner. 45

\footnotetext{
42 Article 2 Act No 21 of 2008 on Sharia Banking.

43 Explain on Act No 21 of 2008 on Sharia Banking.

${ }^{44}$ Peter Mahmud Marzuki, Penelitian Hukum (Jakarta: Kencana Prenada Media, 2010), p. 137.

45 M.D.A. Freeman, Lloyd's Introduction to Jurisprudence (London: Sweet \& Maxwell Ltd, 2001), p. 663
} 
Interestingly, how Peter views the universal prinsiple of sharia banking is quite similar to the view of a numbers of people at Bali who reject sharia banking.

Here, Peter's view (a Christian) and I Gusti Ngurah Arya (a Hindu) is different from Thoby Mutis's view (a Christian) and Hermawan Kertajaya's (a Christian). Both Muti and hermawan agree to the universality Sharia banking principles has. ${ }^{46}$

Explanation above shows that there is also diversity among nonMoslems. With regards to Sharia Banking. Admittedly, the recognition of a number of non-Moslem communities on the universality of sharia banking does make sharia banking capital development is more powerful then before. Indonesia, as a country that is very heterogeneous, requires universal values held strongly by the people in order to be an adhesive nation. In this context, the development of sharia banking that is imbued by universa values is expected to find the momentum.

\section{The Principle of Self-Submission in the Dispute Resolution of Sharia Banking}

Before 2006, the dispute settlement in religious court refers to the principle of Islamic personality. It means that only Moslems can have their cases in religious court $(P A) \cdot{ }^{47}$ Before 2006, there was also a debate on what law to refer to in dispute resolution of sharia economic cases. Muhammad Syafii Antonio stated that the dispute resolution of sharia economic uses sharia law ${ }^{48}$ while Sutan Remy Syahdeini states that civil law is the one to refer to as it is the positive law. ${ }^{49}$ Fortunately, In 2006, exactly since the rising of the Act No 3 of 2006 on Religious Court and strengthened by the Act No 21 of 2008 on Sharia Banking, the principle that prevail in religious court is not only the principle of islamic personality, but also the principle of selfsubmission. It means that in the dispute resolution of sharia economic

46 "Asuransi Syariah, Kaya Manfaat untuk Semua Umat", http://ekonomi. kompasiana. Com.2014, accessed on April 16, 2015.

47 Article 49 Act No 7 of 1989 on Religious Court cmpletely with Act No 3 of 2006 and Act No 48 of 2008 on Religious Court.

48 Muhammad Syafii Antonio, Bank Syariah, Bagi Bankir dan Praktisi Kenangan (Jakarta: Bank Indonesia and Tazkiyah Institute, 1999), p. 30 and p. 214.

${ }^{49}$ Sutan Remi Syahdeini, Perbankan Islam dan Kedudukannya dalam Tata Hukum Perbankan Indonesia (Jakarta: Pustaka Utama Grafiti, 1999), p. 134. 
cases, not only Moslems may enter judgment and punishment in the religious court but also non-Moslem who subjugates themselves on Islamic law namely by becoming customers of sharia banking.

The adding of principle of self-subsmission in religioius courts is to accommodate the dynamics of sharia banking. The actors of sharia banking transaction are not only sharia banking and islamic customers but also between sharia banking and non-Moslem customers. Hence, there is a potential of dispute between sharia banking and non-Moslem customers. Therefore the principle of self-submission in the dispute resolution between sharia banking and non-Moslem customers is absolutely relevant. This is necesseary to avoid the vacuum of norm. Furthermore, the principle of self-submission that accompanies legislation of the Act No 21 of 2008 on Sharia Banking strengthens the universality of religious court. In practical level, the principle of selfsubmission strengthens and expands the function, role, and benefit of religious court.

The dialectic of Moslem and non-Moslem in response to substance of sharia banking Act, both related to the universality of principle of sharia banking and the self-submission principle above shows that there is a specific model of dialogue that uses a relational dialectical thought framework. According to Mikhail Bakhtin, life is an open monologue, mankind finds collision momentum, reject a purpose or provide support in a relational interaction. Baxter confirms that in a dialectical tension, the relation which always develops, succeeds, and is accepted by all parties, it needs continuous attention. ${ }^{50}$

Relational dialectics is based on four basic principles. First, relationship that is always twisting; going up and down with differences of views. Second, relation is always accompanied by dynamics. ${ }^{51}$ The dynamics is the change of relationship quality that effect the articulation of colectivity and independence. ${ }^{52}$ Third, the conflict is a reality in social life. Management of clash of views is not the same and

\footnotetext{
${ }^{50}$ Baxter, A Tale of Two Voices, p. 192.

51 Richard West and Lynn Turner, Pengantar Teori Komunikasi: Analisis dan Aplikasi (Jakarta: Salemba Humanika, 2008), p. 245.

52 William K. Rawlins and Melissa Holl, "Adolescents Interactions with Parents and Friends: Dialectics of Temporal Perspective and Evaluation”, Journal of Social and Personal Relationships, 5 (1988): pp. 27-46.
} 
there is always in a relation. Fourth, dialogue is a needed strategy to nurture and compromise a variety of social conflict. ${ }^{53}$

\section{The Dialectic of Moslem and non-Moslem in the Implemen- tation of Sharia Banking Act}

The study on dialectic of Moslem and non-Moslem in sharia banking implementation focuses on practices and behaviour in the field. This is related to the endorsement or rejection as a response from Moslem and non-Moslem entities.

On August $7^{\text {th }}$ 2014, in front of Bank of Indonesia office, Denpasar, Bali a numbers of youth gathered to state their opinioin against the existence of sharia banking in Bali. Similarly, in some local media, there are some movements opposed everything that correlate with sharia in Bali. ${ }^{54}$ The harsh response associated with the implementation of sharia banking also comes from the Nahdlatul Ulama (NU). According to Syafiq Hasyim, a member of Commission of Bahtsul Masail Diniyah Maudlu'iah Congress of NU 2015th, sharia banking only runs the sharia principle at the beginning of contract. $\mathrm{He}$ further argues that sharia banking actually implements ribawi transaction because it follows conventional banking. Admittedly, sharia banking cannot be separated from practice of usury as the collected money is also used for non-sharia transaction. As the evidence, sharia banking also put his money in the central banks that also operate conventionally. It means, the problem that could not be settled until now by sharia banking is usury. .5

According to Imam Aziz, one of the head of PBNU, sharia bank indeed may not become great. This is because they play in the retail and individual level. Sharia bank tends to resist from crises. Sharia bank is never oriented to macro economic at country level and that is why itis difficult to participate in the global economic competition. ${ }^{56}$

In contrast with several people of Bali and some NU activists, the condition of sharia banking rapidly grows in Medan, North Sumatera. To make it even more interesting, the customers in those sharia bankings in Medan are not only Moslems but also non-Moslems. Non-

\footnotetext{
${ }^{53}$ West and Lynn Turner, Pengantar Teori Komunikasi, p. 246.

54 Agung Sani, Bank Syariah Bukan Ancaman untuk Perekonomian Bali, 08 August 2014, http://ekonomi. kompasiana. Com. 2014, accessed on June 12, 2015.

55 Alhafiz K, Jelang Muktamar Ke-33 NU.

56 Alhafiz K, Jelang Muktamar Ke-33 NU.
} 
Moslem customers admit that sharia banking is interesting because it gives more justice for customers than the conventional banking. This justice is reflected from the fact that profit sharing received by customer depositors (muzarabab) is higher rather than that of the conventional banking.

To give illustraton, at the time of this research, profit sharing level of sharia banking could reach 10 percent while it is only 8.5 percent at the conventional banking. By the profit sharing system, the customer is also not harmed if there is no profit received in murabahah activities (buying and selling). Unsurprisingly, sharia banking is preferable at some places like Medan. ${ }^{57}$

In BNI of Sharia Medan, numbers of customer increasing are marked by the rising credit distribution and financing of third party. BNI Sharia will continue to develop sharia banking networking in various cities in Indonesia, especially in Medan and its surrounding (North Sumatera) as it is seen to promise high prospects. ${ }^{58}$ Similarly, According to the data of Sharia Bank of Mandiri (BSM) branch of Manado, overall there are 1.200 non-Moslem customers who use murabahah scheme financing. ${ }^{59}$ Since 2004, marked by the opening of Bank of Muamalat Indonesia (BMI) Branch of Denpasar, sharia banking rapidly grows in Bali. In just ten years, there have been nine of sharia banks and 1 Sharia Rural Bank in Bali. According to the documentation of Sharia Economic Community (MES) Bali, in Bali there are 59 thousand of customers in 2013, both Moslem and nonMoslem. According to the head of financial service authority (OJK) representatives of Bali, Zulmi, potency of sharia banking in Bali is still very large although the majority of people are non-Moslems. ${ }^{60}$ According to the data of Bank of Muamalat Indonesia (BMI) 2009 Kupang East Nusa Tenggara, there is 8.200 customers. From that number, 3.226 from them are non-Moslems. ${ }^{61}$

${ }^{57}$ Ruslan Burhani, Nasabah Non Moslem Minati Perbankan Syariah, Thursday, December 28, 2006, http://www.antaranews.com, accessed on June 12, 2015.

58 Burhani, Nasabah Non Moslem.

${ }^{59}$ Rejeki, Akad Pembiayaan Murabahah.

60 "Menjawab Resah di Pulau Dewata", http://stabilitas.co.id, accessed on June 21, 2015.

${ }^{61}$ Annaafi M, "Pendapatan dan Pemanfaatan Dana Nasabah non-Moslem. 
Non-Moslem customers in Medan are interested to be customer of Sharia Mandiri Bank (BSM) branch of Medan, because of three factors, namely facilities, promotion, and products. ${ }^{62}$ According to Edhie Rosman, office region head of Sharia Mandiri Bank (BSM) that supervising East Java, Nusa Tenggara, and Bali, although BSM sells sharia concept, but it still positions himself as universal banking that can be acceptable to all citizens, including non-Moslem customers, moreover, many priority customers of BSM are non Moslems. This is evidence that anybody could become BSM partner. ${ }^{63}$

With the growth of sharia banking, the interest to study sharia banking also rapidly grew. In the Trisaksi University Jakarta, the concentration of sharia banking as basic of sharia economic was opened as a choice of department from undergraduate degree (Diploma), Graduate of Islamic Economic (S1 Ekonomi Syariah), Postgraduate and Doctorate Program in Islamic Economic and Finance (IEF). The growth had delivered Thoby Mutis, the rector of the Trisaksi University Jakarta Shariah Economic Award 2004 from the Indonesian Ulama Council and crowned as "The 2010 Sharia Academic Figure" from Investor Magazine. ${ }^{64}$

The dialectics of Moslem and non-Moslem in implementation of sharia banking Act process has been through systematic stages. This case is in line with the opinion of Richard West and Lynn Turner. According to them, there are four ways to resolve the contradiction. First, the change of cycle. Second, segmentation or sorting location to make oppositive sides focus. Third, selection or determination of main scale at various appearing differences. Fourth, integration, combination or synthesis derived from various contradictive relation. ${ }^{65}$

\section{The Integration of Sharia Banking Principle and Local Wisdom in the National Law}

The classical and contemporary reality prove that islamic law is the resume of Islamic intellectuality; the most important manifestation of

\footnotetext{
${ }^{62}$ Evi Yupitri and Raina Linda Sari, "Analisis Faktor-Faktor yang Mempengaruhi non Moslem Menjadi Nasabah Bank Syariah Mandiri di Medan”, Jurnal Ekonomi dan Keuangan, 1, 1 (Des 2012), p. 58. http://jurnal.usu.ac.id, accessed on June 20, 2015.

${ }^{63}$ Rochmat Shobirin, "Bank Syariah Mandiri Malang Raup 10 Miliar", on 24/04/2015, http://malangtimes.com/berita, accessed on June 22, 2015.

64 Burhani, Nasabab Non Moslem.

65 West and Turner, Pengantar Teori Komunikasi, p. 246.
} 
Moslem life model, and the essence of Islamic representation. It is very difficult to enliven Islam if not accompanied by recognizing Islamic law. ${ }^{66}$ Among Islamic intellectual creation, Islamic law is in the top rank and the most popular in world. So, it has given a big contribution to the form of Moslem personal acting, thinking, and attitude. The dynamics of Moslem society contributes significantly to Islamic law. ${ }^{67}$ According to Atho Mudzhar, one product of Islamic law is the legislation in Moslem countries. ${ }^{68}$

In Indonesian context, one of the products of Islamic law is the legislation governing sharia banking; the Act No 21 of 2008 on Sharia Banking (UUPS). Besides being a product of Islamic law, UUPS is also the product of positive law. The juridical position of UUPS as a positive law is stipulated in article 7 of the Act No 12 of 2011 on the Formation of Legislation.

The national legalization for the Sharia Banking Act as a positive law product has a strategic impact. As the national positive law, it will be entitled to be applied effectively by Indonesian people, both Moslems and non-Moslems. However, even after seven years from its enactment (2008-2015), the Act of Sharia Banking does not necessarily obtain positive response from all Indonesian people. Above explanation does illustrate on how both Moslems and non Moslems are not yet in one position regarding sharia banking. There are, as a matter of fact, some Moslems who do not advocate for Sharia banking. And, despite the high number of non-Moslems who chose the sharia bankings, there are still many others who are reluctant. This condition confirms assumption presented by Ann Elizabeth Mayer asserting that the fundamental problem of islamic law codification in islamic country is the conflict between the traditional law that are implemented by Moslem society and the results of islamic law codification instigated by the state. The basic problem which often appears is thelack of

\footnotetext{
${ }^{66}$ Joseph Schacht, An Introduction to Islamic Law (Oxford: Oxford University Press, 1964), p. 1.

67 M. Abid al-Jabiri, Taqwin al-Aql al'Arab (Beirut: Markaz al-Wahdah al-Arabiyah, 1989), p. 96.

68 There are four kind of Islamic Law Thingking Product that known in Islamic law history, i.e. (1) classical book of fiqh, (2) the fatwa of ulama, (3) Decision of Religious Court, and (4) legislation in Islamic Countries. See, M. Atha Mudzhar, Membaca Gelombang Ijtihad: antara Tradisi dan Liberasi (Yogyakarta: Titian Ilahi, 1998), p. 91.
} 
accommodation for traditional Islamic jurisprudence into codified law. ${ }^{69}$

To be worth noting JND Anderson warn that the legislation that contradict community tradition and is not supported by maindstream both community or influential institution will remain ineffective. ${ }^{70} \mathrm{On}$ the other side, when Islam, especially Islamic law, intersect with culture, there will be an elaborative cultural dialogue process. In this situation, Islam will be changing sustainably. But, the changes only occur as long as the text of the Koran and the fundamental normative doctrine of Islam are still established. ${ }^{71}$

In my opinion, law must be at the frontline to control the economic growth. In this case, Trubek concept finds its momentum. He asserts that if law is already positioned accurately, it will be easier to resolve economic problem. An excavation could be done in a proportionate manner to the principle and function of social economic and political law. ${ }^{72}$

The empowerment of sharia economic law in Indonesia requires national law accuration. Social-political living that contradicts sharia economic law implicates failures of the law. Law formulation of sharia economic in Indonesia should refer to the source of materiil law, in this case, islamic law and traditions which are in line with islamic law ('urf sabih). The principle of economic management in the Koran, Sunnah of Rasulullah Saw, and islamic tradition ('urf sahib) will be more optimal in the application in the reality if they are transformed into national legislation. So, the transition of sharia economic value from moral doctrinal normative level into formal legal establishment becomes a necessity in a modern country era today.

69 Ann Elizabeth Mayer, "The Syariah: a Methodology or a Body of Substantive Rules", in Nicholas Heer, Islamic Law and Jurisprudence (Seattle and London: University of Washington Press, 1990), p. 198.

70 JND. Anderson, Hukum Islam di Dunia Modern, trans. Machnun Hussein (Surabaya: Amar Press, 1991), p. 97.

71 Roland Robertson, Agama dalam Analisa Interpretasi Saosiologis (Jakarta: Rajawali, 1988), p. xii

72 David M. Trubek, "Toward a Social Theory of Law: An Essay on the Study of Law and Development", The Yale Law Journal, 82, 1 (November 1972), p. 1. 


\section{Conclusion}

In conclusion, there are three arguments explaining the involvement of Moslems and Non-Moslems in the development of sharia banking: ideological and political argument, juridical and economic argument, and social and cultural argument.

In addition, the dialectic of Moslems and non-Moslems in the development of sharia banking in Indonesia can be found in important aspects, they are the formulation process, the substance, and the implementation of the Act of Sharia Banking. There has always been dialectics trough the development of the Islamic economic and one of the best showcases is in the debates between factions at the DPR RI regarding the proposed bill on Sharia banking. Hegel's model can be used to analyse the flow of the debate. Another interesting point can be concluded is that the development of Islamic bankings turn out to be accepted in the practical realm as the number of customers from non mulims is growing. So, it can be said that despite all the debates and the dialectics, there is a trust to the universality Islamic economic tried to promote in Indonesia. Moreover, the Sharia banking Act and other related acts also allow religious courts to apply the universality as well by being able to handle cases from non-Moslems in the Islamic economic area. []

\section{References}

\section{Books and Articles}

"Opinion of FBPD DPR RI to Bill of Sharia Banking", Memory Risalah (Minute of Meeting), 6 June 2007.

"Opinion of FD DPR RI to Bill of Sharia Banking, Memory Risalah (Minute of Meeting), 6 June 2007.

"Opinion of FPBR DPR RI to Bill of Sharia Banking", Memory Risalah (Minute of Meeting), 6 June 2007.

“Opinion of FPDIP DPR RI to Bill of Sharia Banking”, Memory Risalah (Minute of Meeting), 6 June 2007.

"Opinion of FPDKB DPR RI to Bill of Sharia Banking, Memory Risalah (Minute of Meeting), 6 June 2007. 
"Opinion of FPDS DPR RI to Bill of Sharia Banking", Memory Risalah (Minute of Meeting), 6 June 2007.

al-Jabiri, Muhammad Abid. Taqwin al-Aql al'Arab. Beirut: Markaz alWahdah al-Arabiyah, 1989.

Anderson, JND. Hukum Islam di Dunia Modern, trans. Machnun Hussein. Surabaya: Amar Press, 1991.

Antonio, Muhammad Syafii. Bank Syariah, Bagi Bankir dan Praktisi Keuangan. Jakarta: Bank Indonesia and Tazkiyah Institute, 1999.

as-Sayis, Muhammad Ali. Tarikh al-Fiqh al-Islamy. Egypt: n.p., 1957.

Azizy, Qadri. Hukum Nasional, Eklektisisme Hukum Islam dan Hukum Umum. Jakarta: Teraju, 2004.

Baxter, L. A. "A Tale of Two Voices: Relational Dialectics Theory." The Journal of Family Communication, 4, 3 and 4 (2004).

Benda-Beckmann, Keebet von. "The Context of Law", 8th International Congress of the Commission on Folk Law and Legal Pluralism: Legal Pluralism and Unofficial Law in School, Economic, nd Political Development, Chiang Mai, April 2002.

Erwin, Muhammad. Filsafat Hukum, Refleksi Kritis terhadap Hukum. Jakarta: Raja Grafindo Persada, 2012.

Freeman, M.D.A. Lloyd's Introduction to Jurisprudence. London: Sweet \& Maxwell Ltd, 2001.

Friedman, Lawrence M. The Legal System, a Social Sentence Perspective. New York. Rusell Sage Foundation, 1975.

Griffiths, John "What is Legal Pluralism". Journal of Legal Pluralism and Unofficial Law, 24 (1986).

Ichtiyanto, "Pengembangan Teori Berlakunya Hukum Islam di Indonesia". Eddi Rudiana Arief, Hukum Islam di Indonesia, Perkembangan dan Pembentukan. Bandung: Remaja Rosdakarya, 1994.

Mahfud MD, Moh. Politik. Hukum di Indonesia. Jakarta: LP3ES, 2001.

Marzuki, Peter Mahmud. Penelitian Hukum. Jakarta: Kencana Prenada Media, 2010.

Mayer, Ann Elizabeth. "The Syariah: a Methodology or a Body of Substantive Rules". in Nicholas Heer. Islamic Law and 
Jurisprudence. Seattle and London: University of Washington Press, 1990.

Meek, R.L. D.D. Raphael and P.G. Stein (ed.). Lectures on Jurisprudence. Indianapolis: Liberty Fund, 1982.

Merry, Sally Engle. "Legal Pluralism." in Law and Society Review, 22 (1988).

Miller, A.V. Hegel's preface to the Phenomenology of Spirit. Oxford: Clarendon Press, 1977.

Mudzhar, M. Atha. Membaca Gelombang Ijtibad: antara Tradisi dan Liberasi. Yogyakarta: Titian Ilahi Press, 1998.

Noor, Zainul Bahar. "Sebuah Mimpi, Harapan, dan Kenyataan di Hadapan". paper on One Day Seminar of How to Business in Islamic Perspective, in Garden Palace Hotel Surabaya, September 12, 1992

Rawlins, William K. and Holl, Melissa. "Adolescents Interactions with Parents and Friends: Dialectics of Temporal Perspective and Evaluation." Journal of Social and Personal Relationships, 5 (1988).

Robertson, Roland. Agama dalam Analisa dan Interpretasi Saosiologis. Jakarta: Rajawali Press, 1988.

Schacht, Joseph. An Introduction to Islamic Law. Oxford: Oxford University Press, 1964.

Siddiqi, M. Nejatullah. Issues in Islamic Banking. London: Islamic Foundation, 1983.

Soekanto, Soerjono. Mengenal Sosiologi Hukum. Bandung: Alumni, 1986.

Syahdeini, Sutan Remi. Perbankan Islam dan Kedudukannya dalam Tata Hukum Perbankan Indonesia. Jakarta: Pustaka Utama Grafiti, 1999.

Trubek, David M. "Max Weber on Law and the Rise of Capitalism." Wisconsin Law Review, 3 (1972). -. "Toward a Social Theory of Law: An Essay on the Study of Law and Development." The Yale Law Journal, 82, 1 (November 1972).

UU No 10 Tahun 1998 Tentang Perbankan.

UU No 12 Tahun 2011 Tentang Pembentukan Peraturan Perundangundangan 
UU No 21 tahun 2008 Tentang Perbankan Syariah

UU No 3 Tahun 2006 Tentang Peradilan Agama

UU No 50 Tahun 2009 Tentang Peradilan Agama

UU No 7 Tahun 1989 Tentang Peradilan Agama

UU No 7 Tahun 1989 Tentang Peradilan Agama

UU No 7 Tahun 1992 Tentang Perbankan

West, Richard and Lynn Turner. Pengantar Teori Komunikasi: Analisis dan Aplikasi. Jakarta: PT. Salemba Humanika, 2008.

Yasin, M. Nur. "Argumen-argumen Kemunculan Awal Perbankan Sariah di Indonesia." De Jure, Jurnal Fakultas Syariah UIN Maulana Malik Ibrahim Malang, 2011.

-. "Rekonstruksi Norma Eksekusi Putusan Badan Arbitrase Syariah Nasional dalam Sengketa Ekonomi Syariah di Indonesia." Unpublished dissertation, Doctoral Program of Law, Faculty of Law, University of Brawijaya, 2012.

--------. Hukum Ekonomi Islam. Malang: UIN Malang Press, 2009.

\section{Internet Sources}

"Asuransi Syariah, Kaya Manfaat untuk Semua Umat." http://ekonomi.kompasiana. Com.

"Asuransi Syariah, Kaya Manfaat untuk Semua Umat", http://ekonomi.kompasiana.com.

"Jaringan Kantor Perbankan Syariah.” http:// www.bi.go.id.

"Menjawab Resah di Pulau Dewata." http://stabilitas.co.id.

"Menjawab Resah di Pulau Dewata." http://stabilitas.co.id.

"Prof Thoby Mutis: Bank Syariah Lebih Banyak Kembangkan Musyarakah Fund." http://jaketbiru kampus.blogdetik.com

"Saatnya Dibentuk Peradilan Agama Hindu." http://www.balipost. co.id.

Alhafiz K. Jelang Muktamar Ke-33 NU, PBNU: Bank Berlabel "Syariah" Di Indonesia Belum Syar'i. Ahad, 26/04/2015, http://www.nu.or.id.

Annaafi M, Rizan. "Pendapatan dan Pemanfaatan Dana Nasabah nonMoslem oleh Bank Muamalah Indonesia Cabang Kupang 
NTT." Bachelor thesis, Syariah faculty of UIN Sunan Kalijaga Yogyakarta, 2009. http://digilib.uin-suka.ac.id, accessed on 23 Juni 2015.

Burhani, Ruslan. Nasabah Non Moslem Minati Perbankan Syariah, http://www.antaranews.com

Machmudah, Rifa'atul. Faktor-Faktor Yang Mempengarubi Minat Nasabah Non Moslem Menjadi Nasabah Di Bank Syariah (Studi Pada Bank Cimb Niaga Syariah Cabang Semarang, Fakultas Syariah IAIN Walisongo, 2009. http:/ /ibrary.walisongo.ac.id.

PDS Inginkan Kedamaian dan Hargai Pluralitas, http://www.antaranews.com.

Rejeki, Fanny Yunita Sri. "Akad Pembiayaan Murabahah Dan Praktiknya Pada PT Bank Syariah Mandiri Cabang Manado." Lex Privatum, 1, 2 (Apr-Jun/2013), ejournal.unsrat.ac.id.

Sani, Agung. Bank Syariah Bukan Ancaman untuk Perekonomian Bali. http://ekonomi. kompasiana.com

Sari, Evi Yupitri Dan Raina Linda. "Analisis Faktor-Faktor yang Mempengaruhi non Moslem Menjadi Nasabah Bank Syariah Mandiri di Medan." Jurnal Ekonomi dan Keuangan, 1, 1 (December 2012). http://jurnal.usu.ac.id.

Shobirin, Rochmat. "Bank Syariah Mandiri Malang Raup 10 Miliar." http://malangtimes.com

Sudantra, Ketut. "Pelaksanaan Fungsi Hakim Perdamaian Desa dalam Kondisi Dualisme Pemerintahan Desa di Bali." Unpublished MA thesis, Postgraduate Program, Udayana University. http://sudantra.blogspot.com 